\title{
SCIENTIFIC SUBSTANTIATION OF THE PROCEDURE OF CUSTOMER INFORMING ABOUT THE QUALITY OF DRINKING WATER TAKING INTO ACCOUNT THE REQUIREMENTS OF EUROPEAN LEGISLATION \\ Zorina $\mathbf{0 . V .}$ НАУКОВЕ ОБґРУНТУВАННЯ ПОРЯДКУ ІНФОРМУВАННЯ СПОЖИВАИІВ
ЩОДО ЯКОСТІ ПИТНОӤ ВОДИ З УРАХУВАННММ ВИМОГ
ЕВРОПЕЙСЬКОГО ЗАКОНОДАВСТВА
}

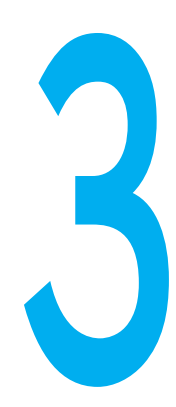

3OPIHA 0.B.

ДУ «Інститут громадського здоров'я ім. О.М. Марзєєва НАМН України», м. Київ

УДК $614.777: 366.6$

Ключові слова: вода питна, європейське законодавство, інформування споживачів, індикаторні показники. набуттям чинності угоди про асоціацію Україна зобов'язується поступово наблизити своє законодавство до законодавства ЄС у встановлені терміни. Так, для Директиви 98/83/ЄС про якість води, призначеної для споживання людиною, передбачено

п прийняття національного законодавства та визначення повноважного органу (органів);

встановлення європейських нормативів щодо якості питної води;

створення європейської системи моніторингу якості природних та питних вод;

$\square$ створення механізму надання інформації споживачам.

Ця робота виконувалася у рамках проекту «Підтримка України в апроксимації європейського законодавства» («Support to Ukraine in approximation of the EU environmental acquis») «APENA projekt» 3 метою імплементації в Україні Директиви 98/83/ЄС щодо води, призначеної для споживання людиною (зі змінами 2015 року)

Мета: наукове обґрунтування та розробка основних критеріїв оцінки та алгоритму прийняття рішень для інформування споживачів щодо якості питної води та стану питного водопостачання на підставі вимог європейського законодавства.

Матеріали. Проведено аналіз європейської та української нормативної документації щодо якості питних вод і необхідності інформування споживачів, оцінку анкетного опитування населення різних населених пунктів України щодо якості водопровідної питної води (загалом 658 анкет).

Методи: бібліографічний, соціологічний (анкетування), санітарно-гігієнічні та експертної оцінки.
НАУЧНОЕ ОБОСНОВАНИЕ ПОРЯДКА

ИНФОРМИРОВАНИЯ ПОТРЕБИТЕЛЕЙ ОТНОСИТЕЛЬНО КАЧЕСТВА ПИТЬЕВОЙ ВОДЫ С УЧЕТОМ ТРЕБОВАНИЙ ЕВРОПЕЙСКОГО ЗАКОНОДАТЕЛЬСТВА

Зорина О.В.

ГУ «Институт общественного здоровья им. А.Н. Марзеева НАМН Украины», г. Киев

Цель: научное обоснование и разработка основных критериев оценки и алгоритма принятия решений для информирования потребителей о качестве питьевой воды и состоянии питьевого водоснабжения на основании требований европейского законодательства.

Материалы: проведены анализ европейской и украинской нормативной документации по качеству питьевых вод и необходимости информирования потребителей, оценка анкетного опроса населения разных населенных пунктов Украины относительно качества водопроводной питьевой воды (658 анкет).

Методы: библиографический, социологический (анкетирование), санитарно-гигиенические и экспертной оценки.

Основные результаты. В статье впервые унифицированы и схематично представлены алгоритмы проведения порядка информирования потребителей о качестве питьевой воды и состоянии питьевого водоснабжения в соответствии с требованиями Директивы 98/83/EC о качестве воды, предназначенной для потребления человеком, с целью скорейшего налаживания в стране механизма информирования потребителей и предупреждения использования водных источников, качество которых не контролируется. Впервые в стране предложено ввести унифицированные формы предоставления информации потребителям питьевой воды и определены условия их информирования. Разработаны критерии оценки качества питьевой воды в случае сверхнормативного содержания «индикаторных показателей».

Ключевые слова: вода питьевая, европейское законодательство, информирование потребителей, индикаторные показатели.

() Зоріна О.В. СТАТТЯ, 2018. 
SCIENTIFIC SUBSTANTIATION

OF THE PROCEDURE OF CUSTOMER INFORMING

ABOUT THE QUALITY OF DRINKING WATER

TAKING INTO ACCOUNT THE REQUIREMENTS

OF EUROPEAN LEGISLATION

Zorina O.V.

State Institution «O.M. Marzeyev Institute for Public Health, NAMSU», Kyiv

Objectives: We scientifically substantiated and developed the basic criteria for the assessment and algorithm of the decision-making for informing of the consumers about quality of drinking water and state of drinking water supply, based on the requirements of European legislation.

Materials and methods: We analyzed European and Ukrainian normative documents on the quality of drinking water and the need for informing of the consumers and evaluated the questionnaire survey of the population on the quality of tap water (658 questionnaires) in different settlements of Ukraine.
We used bibliographic, sociological (questioning), sanitary-and-hygienic methods and method of expert assessment.

Results: This paper is the first to unify and to show schematically the algorithms of the procedure of customer informing about the quality of drinking water and the state of drinking water supply according to the requirements of Directive 98/83/EU on drinking water quality for human consumption in order to establish the customer information mechanism and to prevent the use of water sources without quality control. First in the country, we proposed to introduce the unified forms for informing of the customers of drinking water and defined the conditions of informing. Criteria for drinking water quality assessment in case of the over-standard content of «indicator parameters» were developed.

Keywords: drinking water, European legislation, customer informing, indicator parameters.
Результати досліджень та їх обговорення. На сьогодні в Україні споживачі різних видів питних вод не мають доступу до отримання об'єктивної інформації щодо її якості. За нашою ініціативою у ДСанПіН 2.2.4-171-10 вперше було зобов'язано виробників

口 фасованих питних вод вказувати на етикетці її вид, склад, фактичні значення показників фізіологічної повноцінності мінерального складу питної води, вид вихідної води, місцезнаходження підземного джерела питного водопостачання, номер і глибину свердловини тощо;

$\square$ питних вод із пунктів розливу оформляти листок для споживачів з зазначенням інформації щодо виду, складу, виду вихідної води, місцезнаходження підземного джерела питного водопостачання, номера і глибини свердловини тощо;

$\square$ питної води із бюветів, колодязів чи каптажів джерел у разі невідповідної якості питної води та неможливості її споживання вивішувати інформаційну табличку «Вода для пиття непридатна».

Результати проведеного нами соціологічного дослідження протягом 2013-2015 років шляхом анкетного опитування сільського та міського населення різних областей України (658 осіб різного віку та статі) щодо самостійної оцінки споживачами якості питних вод підтвердили таке. Водопровідну воду для споживання використовують 55,1\% опита-

них, воду із бювета, колодязя та індивідуальних свердловин - 21,3\%, фасовану - 14,8\%, доочищену із пунктів розливу - 8,8\% респондентів. Серед опитаних $70 \%$ оцінюють якість водопровідної питної води в їхніх населених пунктах незадовільною. Серед основних причин відзначали неприємні органолептичні властивості хлорний запах, незвичайний

смак, каламутність [1]. Нами виявлено необізнаність споживачів щодо негативного впливу на їхнє здоров'я питної води з сухим залишком менше 100 мг/л [2-7]. Отже, анкетне опитування підтвердило, що споживачі, оцінюючи якість питної води, опираються лише на суб'єктивні органи чуття, не володіють об'єктивною інформацією та мають недовірливе

\section{Рисунок 1}

Порядок проведення інформування споживачів щодо стану питного водопостачання згідно з вимогами Директиви 98/83/€С

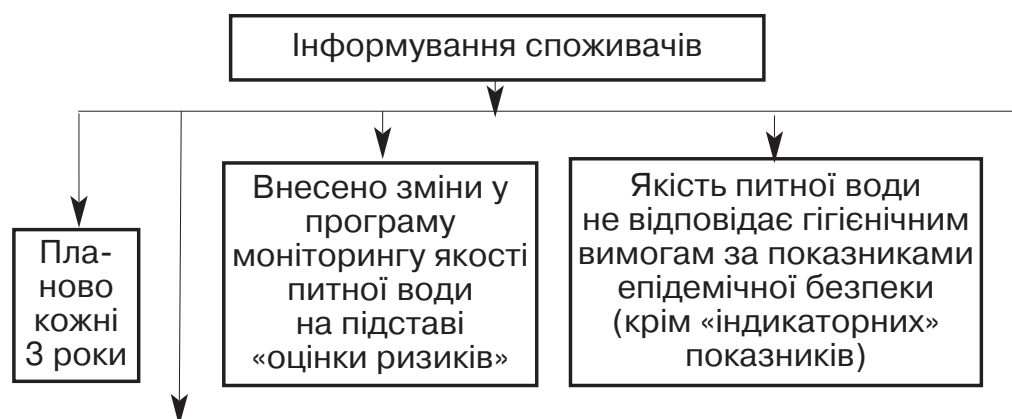

$€$ очевидною потенційна загроза людському здоров'ю через невідповідну якість питної води, але згідно з вимогами законодавства виробник не несе відповідальності за її якість («у внутрішній розподільній мережі») та/або моніторинг її якості не проводиться (в індивідуальних джерелах)

\section{$\checkmark$}

Якість питної води не відповідає гігієнічним вимогам за «індикаторними» показниками

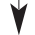

Якість питної води не відповідає гігієнічним вимогам (крім показників епідемічної безпеки та «індикаторних»)

Рис. 2

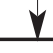

Рис. 3 
води, що були вжиті та плануються.

Інформацією, доступною для громадськості, має стати короткий виклад результатів «оцінки ризику» (рис. 1), що проводиться 3 метою визначення можливості внесення змін до порядку моніторингу якості питної води у пунктах відповідності, наприклад, за стандартом EN 15975-2. Належні програми моніторингу (на підставі оцінки ризиків або без неї) розроблятимуться компетентними органами, розглядатимуться на постійній основі, оновлюватимуться або будуть пролонгованими кожні п'ять років.

Інформування споживачів проводиться також у випадках, коли погіршується якість питної води у зовнішній або внутрішній водопровідній мережі шкіл, лікарень тощо, а також у тих, що належать виробникам питної води. Нами розроблені уніфіковані форми для інформування (табл.).

Згідно з Директивою 98/83/ЄС у випадку понаднормативного вмісту індикаторного (-их) показника (-ів) (рис. 1) компетентний орган повинен вирішити, чи становить відповідна якість питної води певний ризик для здоров'я споживачів, та інформувати їх у випадку можливого негативного впливу (рис. 2).

Такий підхід, на нашу думку, зумовлений несуттєвою бар'-

другий - про за ди з поліпшення якості питної

Уніфіковані форми для інформування споживачів

Таблиця та умови їх застосування (Директиви 98/83/ЄС)

\begin{tabular}{|c|c|}
\hline Уніфіковані форми & Умови інформування \\
\hline $\begin{array}{c}\text { Про заборону використання питної } \\
\text { води: «Не використовувати для } \\
\text { будь-яких цілей, у тому числі для пиття, } \\
\text { приготування їжі, чищення зубів, } \\
\text { купання, прийняття душу, прання } \\
\text { тощо». }\end{array}$ & $\begin{array}{c}\text { - якість питної води } \\
\text { не відповідає гігієнічним } \\
\text { вимогам за «індикаторними» } \\
\text { показниками (рис. 2) або }\end{array}$ \\
\hline \begin{tabular}{|c|} 
Про необхідність обмеженого \\
використання питної води: \\
- «кип'ятити перед споживанням, \\
приготуванням їжі, чищенням зубів, \\
частіше проводити мийку та \\
дезінфекцію побутової санітарної \\
техніки»; \\
- «не використовувати для пиття і при- \\
готування їжі, чищення зубів. Можливо \\
використовувати для купання, \\
прийняття душу, в унітазах тощо».
\end{tabular} & $\begin{array}{c}\text { не відповідає гігієнічним } \\
\text { вимогам (крім показників } \\
\text { епідемічної безпеки та } \\
\text { «індикаторних) (рис. 3) або } \\
\text { - якість питної води } \\
\text { не відповідає гігієнічним } \\
\text { вимогам за показниками } \\
\text { епідемічної безпеки } \\
\text { (крім «індикаторних» } \\
\text { показників). }\end{array}$ \\
\hline
\end{tabular}

єрною здатністю традиційних споруд водопровідних станцій щодо цих показників, їхньою. органолептичною ознакою шкідливості або непрямим впливом на здоров'я споживачів. У Директиві відсутній алгоритм прийняття рішень щодо безпеки питної води у разі наднормативного вмісту індикаторних показників. На підставі багаторічних досліджень якості усіх видів питних вод та вивчення їхнього впливу на здоров'я споживачів нами визначено, що у разі прийняття відповідних рішень необхідно брати до уваги такі критерії оцінки (рис. 2): частоту і кратність перевищення показником гігієнічного нормативу (необхідно враховувати, що суттєвість перевищення нормативу оцінюється для кожного показника індивідуально), клас небезпеки і його лімітуючу ознаку шкідливості, кількість показників у наднормативних концентраціях, причини їх наявності у воді, відсутність негативного впливу на показники епідемічної безпеки, фонові концентрації у воді джерела, місцеві умови, фактичну захворюваність споживачів з цієї причини (за епідеміологічними дослідженнями) та інше. Крім того, слід прийняти за орієнтовні такі чинні нині гігієнічні нормативи: для амонію - 2,6 мг/л; алюмінію 0,5 мг/л; натрію - 200 мг/л; заліза - 1,0 мг/л; марганцю 0,5 мг/л; хлоридів - 350 мг/л; сульфатів - 500 мг/л; сухого залишку - 1500 мг/л, кольоровості - 35 градусів, каламутності - 3,5 НОК. Рішення щодо можливості підняття нормативу для індикаторного (-их) показника (-ів) має прийматися у кожному конкретному випадку за визначених науково обґрунтованих умов.

У випадку, коли якість питної води не відповідає гігієнічним вимогам (крім показників епідемічної безпеки та «індикаторних») (рис. 1), слід застосовувати розроблений нами алгоритм (рис. 3).

Компетентний орган надає консультаційну допомогу споживачам щодо якості питної води та заходів, які вони самостійно можуть вжити, з метою попередження захворюваності через невідповідність якості питної води нормативним вимогам у разі погіршення 
якості питної води у зовнішній або внутрішній розподільній мережі, що не належить виробнику питної води (крім лікарень, шкіл тощо) (рис. 3). Згідно з Директивою 98/83/ЄС «внутрішня розподільна мережа»-мережі, арматура на них, прилади та обладнання, засоби обліку та регулювання споживання житлово-комунальних послуг, які розміщені між кранами, що зазвичай використовуються споживачем, та зовнішньою розподільною мережею, але лише у тому разі, якщо вони не перебувають у межах відповідальності водопостачальника згідно з вимогами законодавства.

У випадку, коли питна вода із систем питного водопостачання, призначених для особистого використання, і продуктивністю менше $10 \mathrm{~m}^{3}$ на добу у середньому (або питну воду використовують менше 50 осіб) не надходить 3 комерційною метою або для громадського використання, то моніторинг якості такої води може не проводитися. У такому випадку споживачі зазначеної питної води мають бути поінформованими про це і про заходи, які можуть бути прийняті для захисту їхнього здоров'я у разі забруднення питної води.

Таким чином, на сьогодні актуальною $€$ розробка механізму надання інформації споживачам питної води з метою попередження випадків використання вододжерел, якість яких не контролюється, та забороною споживання населенням забрудненої води.

\section{Висновки}

1. Підтверджено результатами соціологічного дослідження (658 анкет), проведеного у різних населених пунктах України, що споживачі, оцінюючи якість питної води, спираються лише на суб'єктивні органи чуття, не володіють об'єктивною інформацією та мають недовірливе ставлення до якості водопровідної питної води.

2. Вперше у країні з метою імплементації європейського законодавства уніфіковано та доопрацьовано алгоритм прийняття рішень для інформування споживачів щодо якості питної води та стану питного водопостачання; розроблено критерії оцінки якості питної води у разі понаднормативно- го вмісту індикаторного (-их) показника (-ів) з метою прийняття управлінських рішень та розв'язання кризи у сфері централізованого питного водопостачання. За рекомендаціями ВООЗ запропоновано уніфіковані форми надання інформації споживачам у випадку невідповідної якості питної води та визначено умови їх застосування

3. Визначено основне завдання роботи механізму надання інформації споживачам - викликати довірливе ставлення споживачів до виробників питної води та попередити випадки використання вододжерел для питних потреб, якість яких не контролюєТься.

\section{ЛІТЕРАТУРА}

1. Липовецька О.Б. Якість водопровідної питної води за результатами анкетного опитування населення. Український науково-медичний журнал. 2014. № 4 (83). С. 64-65.

2. Прокопов В.О. Питна вода України: медико-екологічні та санітарно-гігієнічні аспекти. К. : Медицина, 2016. 400 с.

3. Гігієнічні вимоги до води питної, призначеної для спо- живання людиною : ДСанПіН 2.2.4-171-10 / МОЗ України. Київ, 2010. 55 с.

4. Зуев Е.Т., Фомин Г.С. Питьевая и минеральная вода. Требования мировых и европейских стандартов к качеству и безопасности : монография. Москва, 2003. 320 c.

5. Грищенко Н.С., Фрог Н.П. О новых подходах решения проблемы обеспечения населения питьевой водой. Збірник доповідей Міжнарод. конгресу ЕТЕВК-2005. К., 2005. C. $243-247$

6. Гончарук В.В. Концепция выбора перечня показателей и их нормативных значений для определения гигиениче-

Рисунок 2

\section{Порядок проведення інформування споживачів у разі невідповідності якості питної води гігієнічним вимогам за «індикаторними» показниками}

Якість питної води не відповідає гігієнічним вимогам за «ндикаторними» показниками

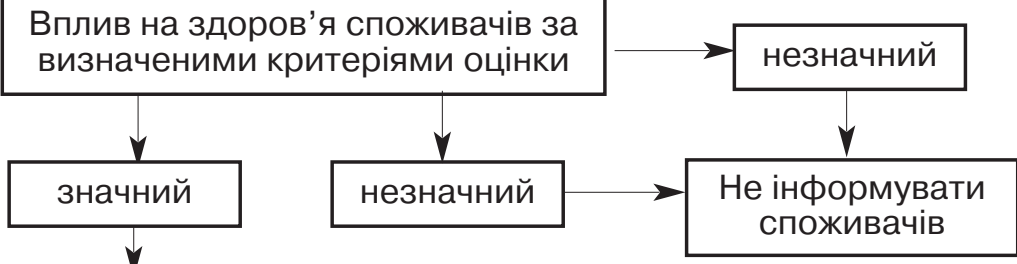

$\checkmark$

Інформування споживачів

$\square$ про якість питної води

$\square$ про заборону використання питної води:

«Не використовувати для будь-яких цілей, у тому числі для пиття, приготування їжі, чищення зубів, купання, прийняття душу, прання тощо»;

про необхідність обмеженого використання питної води: «Кип'ятити перед вживанням, приготуванням їжі, чищенням зубів, частіше проводити мийку та дезінфекцію побутової санітарної техніки», «Не використовувати для пиття приготування їжі, чищення зубів.

Можна використовувати для купання, прийняття душу, в унітазах» тощо;

$\square$ про заходи, які вони самостійно можуть вжити з метою попередження захворюваності. 
води. 2007. № 4 (29). С. 297 356.

7. Комунальна гігієна / за ред. Є.І. Гончарука та ін. К. : Здоров'я, 2006. 792 с.

8. Шестопалов В.М., Овчиннікова Н.Б. Перша українська класифікація мінеральних вод. Вода і водоочисні технології. 2003. № 3 (7). С. 34-42.

9. Schmoll O., Howard G. Chilton J. and Chorus I. (Eds.) Protecting Groundwater for Health : Managing the Quality of Drinking-water Sources.

ских требований и контроля за качеством питьевой воды в Украине. Хімія і технологія

London: WHO; 2006 : 175 p. URL : http://www.who.int/

Рисунок 3

Порядок проведення інформування споживачів у разі невідповідності якості питної води гігієнічним вимогам (крім показників епідемічної безпеки та «індикаторних»)

Якість питної води не відповідає гігієнічним вимогам (не розглядаються показники епідемічної безпеки та «індикаторні»)

Виробник несе відповідальність за якість питної води

\begin{tabular}{|c|}
\multicolumn{1}{c|}{} \\
консультаційна \\
допомога спожива- \\
чам щодо заходів, \\
які вони самостійно \\
можуть вжити \\
з метою \\
попередження \\
захворюваності \\
\hline
\end{tabular}

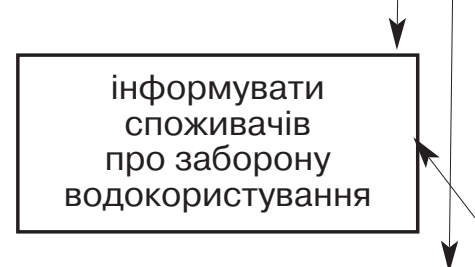

інформувати споживачів про необхідність обмеженого водокористування
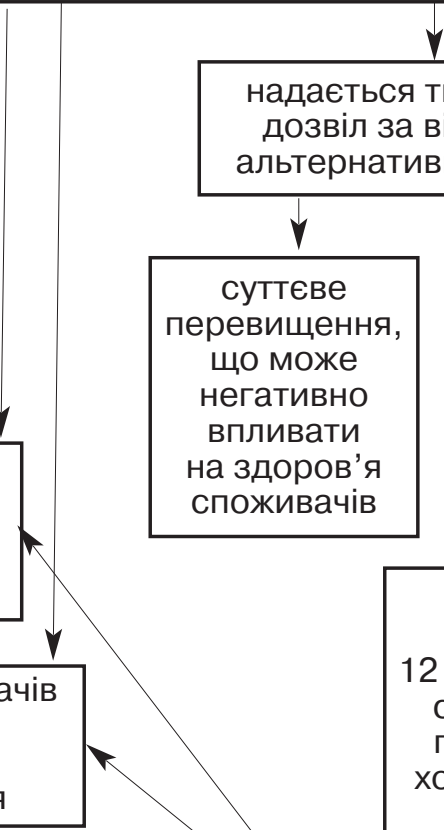

$Y$ інформувати споживачів про якість питної води

інформувати споживачів про заходи що вживаються з метою поліпшення якості питної води

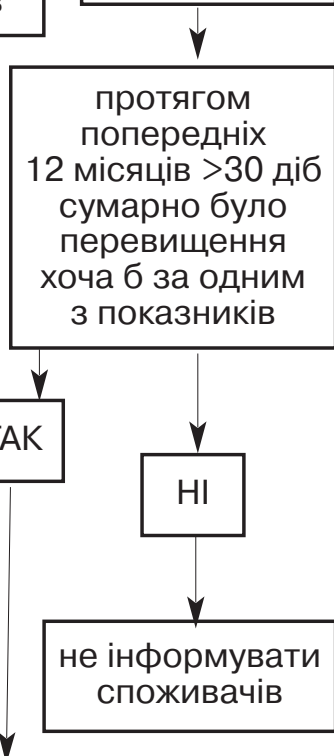

консультаційна допомога окремим групам населення, для яких відповідна якість питної води може становити особливий ризик water_sanitation_health/publications/PGWsection 1.pdf

REFERENCES

1. Lypovetska O.B. Ukrainskyi naukovo-medychnyi zhurnal. 2014 ; 4 (83) : 64-65

(in Ukrainian).

2. Prokopov V.O. Pytna voda Ukrainy: medyko-ekolohichni ta sanitarno-hihiienichni aspekty [Drinking Water of Ukraine:

Medico-Ecological and

Sanitary-and-Hygienic

Aspects]. Kyiv : Medytsyna;

2016 : 400 p. (in Ukrainian).

3. Hihiienichni vymohy do vody pytnoi, pryznachenoi dlia spozhyvannia liudynoiu :

DSanPiN 2.2.4-171-10.

[Hygienic Requirements to Drinking Water for Human Consumption]. Kyiv ; 2010 : 55 p. (in Ukrainian).

4. Zuev E.T. and Fomin G.S.

Pitievaia i mineralnaia voda.

Trebovaniia mirovykh i evropeiskikh standartov k kachestvu i bezopasnosti [Drinking and Mineral Water.

Requirements of the World and European Standards to the Quality and Safety]. Moscow ; 2003 : 320 p. (in Russian).

5. Grishchenko N.S. and

Frog N.P. O novykh podkhodakh resheniya problem obespecheniya naseleniya pitievoy vodoy [On the New Approaches to the Solution of the Problem in the Supply of the Population with Drinking Water]. In :

Zbirnyk dopovidei

Mizhnarodnoho konhresu

ETEBK-2005 [Reports

Collection of the International

Kongress ETEVK-2005]. Kyiv ; 2005 : 243-247 (in Russian)

6. Goncharuk V.V. Khimiia i tekhnolohiia vody. 2007 ; 4 (29)

: 297-356 (in Russian).

7. Goncharuk Ye.l. (ed.)

Kommunalnaya gigigena : uchebnik [Communal Hygiene: Textbook]. Kyiv : Zdorovia ; 2006 : 792 p. (in Russian).

8. Shestopalov V.M. and Ovchynnikova N.B. Voda $i$ vodoochysni tekhnolohii. 2003 ; 3 (7) : 34-42. (in Ukrainian). 9. Schmoll O., Howard G. Chilton J. and Chorus I. (Eds.) Protecting Groundwater for Health : Managing the Quality of Drinking-water Sources. London : WHO ; 2006 : 175 p. URL : http://www. who.int/ water_sanitation_health/publications/PGWsection 1.pdf

Надійшло до редакції 08.05.2018 